\title{
Études/Inuit/Studies
}

\section{DALEY,Patrick J. and Beverly A. JAMES, 2004 Cultural Politics and the Mass Media: Alaska Native Voices, Urbana and Chicago, University of Illinois Press, 235 pages.}

\section{Valerie Alia}

Volume 29, numéro 1-2, 2005

Préserver la langue et les savoirs

Preserving language and knowledge

URI : https://id.erudit.org/iderudit/013951ar

DOI : https://doi.org/10.7202/013951ar

Aller au sommaire du numéro

\section{Éditeur(s)}

Association Inuksiutiit Katimajiit Inc.

Centre interuniversitaire d'études et de recherches autochtones (CIÉRA)

ISSN

0701-1008 (imprimé)

1708-5268 (numérique)

Découvrir la revue

Citer ce compte rendu

Alia, V. (2005). Compte rendu de [DALEY,Patrick J. and Beverly A. JAMES, 2004 Cultural Politics and the Mass Media: Alaska Native Voices, Urbana and

Chicago, University of Illinois Press, 235 pages.] Études/Inuit/Studies, 29(1-2),

348-351. https://doi.org/10.7202/013951ar d'utilisation que vous pouvez consulter en ligne. 
Particular attention is given to Boas' experiences while staying among the Inuit of southern Baffin Island in the 1880s and how he conveyed his views of Inuit and the Arctic to his children and grandchildren. This section is of particular interest to arctic social scientists. The chapters are organized chronologically focussing in Boas' personal and academic career, immigration to the USA, personal ordeals, political activism, and legacy. These chapters are based on original archival materials housed with the American Philosophical Society in Philadelphia, PA, but also draw from documents in private collection of Boas family members.

The Epilogue includes the description of the encounter, in the 1980s, between members of the Boas family and the Kwakwa'wakw in Alert Bay, British Columbia, with whom Boas worked between the 1880s and 1930s and in particular with one of their members, George Hunt. This moving story shows the closing of a circle that begun with Boas and ended in mediation and conciliation, when materials entailing knowledge where returned by the Boas family — an extraordinary event.

This timely book adds to the wealth of literature on Franz Boas who has kept many cultural anthropologists occupied to ponder about his work and approach to study the difference in human expressions. Norman F. Boas is to be congratulated for his persistence and energy to complete and publish this biography.

\author{
Ludger Müller-Wille \\ Department of Geography \\ McGill University \\ Montréal (Québec) H3A 1Y1 \\ Canada \\ ludger.muller-wille@mcgill.ca
}

DALEY, Patrick J. and Beverly A. JAMES

2004 Cultural Politics and the Mass Media: Alaska Native Voices, Urbana and Chicago, University of Illinois Press, 235 pages.

This is a long overdue and much welcome study of indigenous media in Alaska, which places the media firmly in historical, political, and cultural context. In part, it is a political history of efforts by Alaska Native peoples to challenge state and federal policies and activities, making it an excellent teaching resource for programmes in political and social sciences as well as media and cultural studies. It outlines the political machinations and manoeuvrings that have constantly threatened-and continue to threaten - the cultures, lives, and livelihood of Alaska Natives and the overall integrity and survival of Alaskan flora, fauna, lands and waters. Also included are a helpful list of abbreviations and a few well-chosen maps and illustrations.

The very interesting and thoughtful introductory discussion of Alaska Natives' use of mass media to challenge Euro-American cultural hegemony is followed by a chapter outlining indigenous experiences of missionary interventions and the role of mass 
media in helping to clarify and amplify voices of indigenous resistance. Chapters two and three-case studies of the Alaska Fisherman and the Tundra Times-are the strongest, in terms of successfully and carefully linking theory to experience. In a reversal of the order one might expect, the two strong case studies are followed by two more broadly based chapters on cultural politics, Alaska Native radio and television, and a concluding section that does not quite live up to its intention of summarising cultural politics and indigenous public spheres.

Drawing on Mary Louise Pratt's (1992) theory of transculturation in "the contact zone," the authors consider the emergence of the Tundra Times as an Alaska Native Brotherhood (ANB) lobbying tool in the conflict between indigenous and commercial fisheries. They see the ANB as an amalgamation of Tlingit cultural persistence with "Presbyterian Americanization," embodied in its "White" boarding school-educated Tlingit leader, William Paul (p. 62). Skilfully adapting Tlingit Raven narratives to political expediency, Paul linked Raven's silencing of the people he controlled to the need of indigenous people to control the press, reappropriating "the White man's journalism" to the needs of indigenous Alaskans (p. 64). This discussion of William Paul's approach calls to mind the more recent work of Gloria Bird and Joy Harjo (1997), and their characterization of indigenous writers' English-language poetry and prose as "reinventing the enemy's language."

The Tundra Times bolstered Alaska Native resistance efforts by giving voice to a pan-indigenous movement that managed (however imperfectly) to unite Aleut, Yup'ik, Inupiat, Athabascan, Tlingit, Haida and Tsimshian peoples. With the newspaper front and centre, the movement's best known and farthest-reaching achievement was the signing of the Alaska Native Claims Settlement Act (ANCSA). The prime mover in that process was the Seattle-educated artist and Inupiat leader, Sikvoan Weyahok (Howard Rock). The story of the Tundra Times, which ceased publication in 1997, has striking resonance for today. While they are correct in terms of that newspaper's specific history, the authors present an incomplete portrait of the paper's historical and international significance. Relegating its crucial seasons to the 1960s and 70s, they suggest that from then on, it steadily weakened until it finally died. It would be useful to consider the paper's continuing effects and influences in a changing political and media culture - its media afterlife-in Alaska and elsewhere. In light of the present United States government's obsession with oil and the continuing assaults on Alaska resources and lands, the need for a Tundra Times is greater than ever.

Daley and James understand the emergence of Tundra Times as a conflict between subsistence and technocracy, a history quite different from that of indigenous media in Canada. Unlike the situation in the Canadian North, with its array of technologically sophisticated broadcast and telecommunication services, such services in Alaska have been erratic at best and more often, nonexistent. It is unfortunate that, like so much U.S. scholarship, this U.S.-centric view ignores the peoples, policies and precedents of Alaska's Canadian next-door neighbours. Even though the book's central analysis is framed in Gail Guthrie Valaskakis' idea of "resistance as cultural persistence," Valaskakis is never identified as an indigenous scholar whose theory is rooted in Canadian communications and policies, and in the experiences of indigenous peoples in 
Canada. It is a serious omission, especially in the case of precedent-setting satellite communications, which involved indigenous people from the start, and evolved into the international programming and Canada-wide distribution of the Aboriginal People's Television Network (APTN).

In particular, the discussion of the Yup'ik broadcast outlet, KYUK, would benefit from comparison with developments in Canada. More broadly, the examination of Alaska Native broadcasting would be clarified and enriched by considering the influence of Canadian indigenous media, media technologies and media networks on indigenous media in Alaska and internationally (e.g., Alia 1999; Roth with Valaskakis 1989; Roth 2005). Certainly, Alaska Eskimos have done this, as active participants in the international Inuit Circumpolar Conference (ICC).

The conclusion sketches a perspective on cultural politics and media and returns to Valaskakis' idea of resistance as cultural persistence. It briefly considers some developments in Alaska Native broadcasting and more briefly, the Alaska Native sovereignty movement in international context. Rather than bringing the prior analysis more sharply into focus, the conclusion scatters seeds from recent and current political and media developments and leaves them for the reader to gather and carry forward. It would seem relevant to address some of the possible ways forward, in which to strengthen, restore, and further the dissemination of indigenous media voices and create and maintain indigenous media outlets. Finally, the reader is called upon to learnfrom the two case studies and the broader cultural and historical documentation-to listen to Alaska Native voices. The implicit assumption that readers will not themselves be Alaska Natives seems a contradiction of the spirit and substance of the book.

\section{References}

ALIA, Valerie

1999 Un/Covering the North: News, Media and Aboriginal People, Vancouver, University of British Columbia Press.

HARJO, Joy and Gloria BIRD

1997 Reinventing the Enemy's Language, New York, W.W. Norton.

PRATT, Mary Louise

1992 Imperial Eyes. Travel Writing and Transculturation, London, Routledge.

ROTH, Lorna

2005 Something New in the Air, Kingston and Montreal, McGill-Queen's University Press. 


\title{
ROTH, Lorna and Gail Guthrie VALASKAKIS
}

1989 Aboriginal Broadcasting in Canada in M. Raboy and P.A. Bruck (eds), Communication for and against Democracy, Montreal, Black Rose.

\author{
Valerie Alia \\ (Leeds Metropolitan University) \\ 24 Liddell Court \\ Sunderland SR6 0RH \\ United Kingdom \\ v.alia@leedsmet.ac.uk
}

\section{DAMAS, David \\ 2002 Arctic Migrants / Arctic Villagers. The Transformation of Inuit Settlement in the Central Arctic, Montréal et Kingston, McGill-Queen's University Press, 277 pages.}

Dans ce livre, David Damas explore les changements survenus dans les structures d'occupation du territoire (patterns of settlement) des Inuit de l'Arctique central canadien au cours des années cinquante et soixante du vingtième siècle. Pour ce faire, l'auteur analyse les facteurs socio-politiques qui ont favorisé la sédentarisation des Inuit. Il part de deux constats. Premièrement, la sédentarisation est un mouvement double qui implique une action gouvernementale concertée (réinstallation ou établissement de politiques sociales) et un désir des populations locales de vivre dans les communautés nouvellement créées (migration). Deuxièmement, les politiques gouvernementales à l'égard des Inuit se sont renversées entre le début et la fin des années cinquante. D'une politique de dispersion qui visait à encourager les Inuit à occuper le territoire, le gouvernement change son fusil d'épaule au milieu des années cinquante et met en place des politiques sociales qui les encouragent à se sédentariser.

Damas appuie sa discussion sur des données puisées d'une part dans le corpus anthropologique et historique touchant à tout l'Arctique central et d'autre part dans divers fonds des Archives nationales du Canada, du Prince of Wales Heritage Centre à Yellowknife ainsi que des Archives de la Compagnie de la Baie d'Hudson à Winnipeg. Le livre comporte huit chapitres qui sont accompagnés de 54 pages de notes, d'une bibliographie et d'un index exhaustif.

Dans les premières pages du livre, l'auteur décrit la notion de structure d'occupation du territoire. Cette structure est composée de quatre éléments: la location des camps, la durée d'occupation, la taille du groupe et le type de regroupement. Plusieurs facteurs influencent la structure d'occupation du territoire, mais c'est le facteur économique qui possède l'influence la plus importante. Par nécessité, le groupe devra occuper le territoire de manière à se procurer les ressources qui lui permettront d'être économiquement viable. Cependant, des facteurs symboliques (fêtes, cérémonies, interdits) ou des facteurs familiaux ont également une influence sur les aspects de la structure d'occupation. 